\title{
PENERAPAN MODEL PEMBELAJARAN ADVANCE ORGANIZER UNTUK MENINGKATKAN HASIL BELAJR IPS (ILMU PENGETAHUAN SOSIAL) SISWA KELAS VII MTS AL-KIRIYAH TEGALLINGGAH KABUPATEN BULELENG 2018/2019
}

\author{
L. Fildzaka Washilul Atsery ${ }^{1}$, lyus Akhmad Haris², Luh Indrayani \\ Program Studi Pendidikan Ekonomi \\ Universitas Pendidikan Ganesha \\ Singaraja, Indonesia \\ e-mail: jatsery@gmail.com¹, akhmad.haris@undiksha.ac.id², \\ luh indravani@undiksha.ac.id ${ }^{3}$.
}

\begin{abstract}
Abstrak
Tujuan penelitian ini untuk mengetahui apakah penerapan model pembelajaran advance organizer dapat meningkatkan hasil belajar IPS (IImu Pengetahuan Sosial) siswa kelas VII di MTs AI-Khairiyah. Penelitian ini merupakan penelitian tindakan kelas yang dilaksanakan dalam dua siklus dengan tahapan-tahapan setiap siklus meliputi perencanaan, pelaksanaan, observasi, pengamatan, dan refleksi. Jenis data adalah data kuantitatif. Metode pengumpulan data hasil belajar siswa adalah metode tes (pre-test dan post-test). Hasil penelitian menunjukan penerapan model pembelajaran advance organizer dapat meningkatkan hasil belajar. Pada siklus I nilai rata-rata hasil belajar siswa sebesar 70,65 yang berada dalam kategori cukup. Ketuntasan belajar mengalami peningkatan sebesar $13,04 \%$ dari $47,83 \%$ pada observasi awal menjadi $60,87 \%$ pada akhir siklus I, sedangkan pada siklus II nilai rata-rata hasil belajar siswa mengalami peningkatan menjadi 80,65 yang berada pada kategori baik. Ketuntasan belajar juga mengalami peningkatan yang dapat dikatakan sangat tinggi yaitu sebesar $34,78 \%$ dari $60,87 \%$ pada akhir siklus I menjadi $95,65 \%$ pada akhir siklus II.
\end{abstract}

Kata kunci: Hasil Belajar, Advance Organizer, Ilmu Pengetahuan Sosial.

\begin{abstract}
The purpose of this study is to determine application of advanced organizer learning models can improve the learning outcomes of Social Sciences (Social Sciences) VII grade students at MTs AI-Khairiyah. This research is a classroom action research carried out in two cycles with the stages of each cycles covering planning, implementation, observation, observation, and reflection. The type of data is quantitative data. The method of collecting student learning outcomes data is the test method (pre-test and post-test). The results of the study show that the application of advanced organizer learning models can improve learning outcomes. In the first cycle the average value of student learning outcomes amounted to 70.65 which is in the sufficient category. Learning completeness has increased by $13.04 \%$ from $47.83 \%$ in the initial observation to $60.87 \%$ at the end of the first cycle, while in the second cycle the average value of student learning outcomes has increased to 80.65 which is in the good category. Mastery learning also experienced an increase that can be said to be very high, amounting to $34.78 \%$ from $60.87 \%$ at the end of the first cycle to $95.65 \%$ at the end of cycle II.
\end{abstract}

Keywords: Learning Outcomes, Advance Organizer, Social Science 


\section{PENDAHULUAN}

Dalam Undang-Undang (Depdiknas, n.d.) Republik Indonesia Nomor 20 Tahun 2003 tentang Sistem Pendidikan Nasional (SISDIKNAS) bab II Pasal 3 disebutkan bahwa: Pendidikan nasional berfungsi mengembangkan kemampuan dan membentuk watak serta peradaban bangsa yang bermartabat dalam rangka mencerdaskan kehidupan bangsa, bertujuan untuk berkembangnya potensi peserta didik agar menjadi manusia yang beriman dan bertakwa kepada Tuhan Yang Maha Esa, berakhlak mulia, sehat, beriman, cakap, kreatif, mandiri, dan menjadi warga negara yang demokratis serta bertanggung jawab.

Penyempurnaan kurikulum secara berkala diharapkan dapat memberikan sumbangan positif dalam upaya meningkatkan mutu pendidikan nasional. Kurikulum yang berlaku sekarang adalah Kurikulum 2013 di SD, SLTP (SMP, MTs), SLTA (SMA,MA). Kurikulum 2013 pada dasarnya adalah pengembangan dari kurikulum berbasis kompetensi, yang dikembangkan dengan berbasis pada kompetensi, bertujuan untuk menjadikan peserta didik sebagai, manusia berkualitas yang mampu dan proaktif menjawab tantangan zaman yang selalu berubah, manusia terdidik yang beriman dan bertakwa kepada Tuhan Yang Maha Esa, berakhlak mulia, sehat, berilmu, cakap, kreatif, mandiri, dan warga negara yang demokratis dan bertanggung jawab. Untuk mendukung pencapaian tersebut maka pengembangan potensi peserta didik harus disesuaikan dengan potensi, perkembangan, kebutuhan, kepentingan peserta didik, serta keadaan dan tuntutan lingkungan di sekitarnya. Tuntutan pengembangan Kurikulum 2013 itu ditujukan kepada semua mata pelajaran termasuk mata pelajaran IPS. Adapun tujuan dari pembelajaran IPS menurut silabus pelajaran IPS tahun 2013 di SMP/MTs yaitu: pertama memiliki perilaku yang mencerminkan sikap orang beriman, berakhlak mulia, berilmu, percaya diri, dan bertanggung jawab dalam berinteraksi secara efektif dengan lingkungan sosial dan alam serta dalam menempatkan diri sebagai cerminan bangsa dalam pergaulan dunia, kedua memiliki pengetahuan faktual, konseptual, prosedural, dan metakognitif dalam ilmu pengetahuan, teknologi, seni dan budaya dengan wawasan kemanusian, kebangsaan, kenegaraan, dan peradaban terkait penyebab serta dampak fenomena dan kejadian, ketiga memiliki kemampuan pikir dan tindak yang efektif dan kreatif dalam ranah abstrak dan konkret sebagai pengembangan dari yang dipelajari di sekolah secara mandiri.

Hasil observasi pembelajaran IPS yang dilakukan di kelas VII MTs Alkhairiyah pada tanggal 25 Agustus 2018 dapat digambarkan proses pembelajaran belum mencapai tujuan yang maksimal, hal ini dapat dilihat dari hasil belajar siswa pada mata pelajaran IPS. Rendahnya hasil belajar siswa tampak dari rata-rata nilai Ulangan Tengah Semester (UTS) siswa kelas VII pada awal semester ganjil tahun pelajaran 2017/2018. Hal tersebut dapat dilihat dari rata-rata nilai hasil belajar mata pelajaran IPS siswa kelas VII adalah 67,70 dengan nilai tertinggi 80 dan nilai terendah 50 sedangkan Kriteria Ketuntasan Minimal (KKM) untuk mata pelajaran IPS di MTs AL-khairiyah Tegallinggah adalah 70. Dari KKM tersebut dapat diketahui siswa yang sudah tuntas sebanyak 11 orang $(47,83 \%)$ dan siswa yang tidak tuntas sebanyak 12 orang $(52,17 \%)$, dengan jumlah siswa 23 orang.

Dari hasil obserasi tersebut dapat dinyatakan bahwa siswa kelas VII MTs Alkhairiyah Tegallinggah hasil belajarnya belum maksimal. Berdasarkan hasil penelitian awal proses pembelajaran di kelas dan hasil wawancara yang dilakukan dengan guru pelajaran IPS dan siswa terdapat permasalahan yang berhasil diidentifikasi secara umum sebagai berikut: pertama siswa kurang aktif bertanya pada saat guru menjelaskan materi dan siswa hanya menjawab saat guru memberikan pertanyaan, rata-rata berjumlah 9 siswa, keedua siswa kurang terbiasa belajar mandiri, berjumlah 7 siswa, keiga dalam kegiatan diskusi siswa cenderung pasif berjumlah 6 siswa.

Bertolak dari permasalahan tersebut, maka dalam rangka meningkatkan hasil belajar perlu diterapkannya suatu pembelajaran inovatif 
yang dapat melibatkan siswa secara aktif baik fisik maupun psikologis dalam setiap kegiatan pembelajaran, sehingga mampu untuk meningkatkan hasil belajar IPS siswa. Model pembelajaran yang tepat digunakan untuk memecahkan masalah tersebut adalah model pembelajaran advance organizer. Model pembelajar advance organizerpertama kali dikembangkan oleh Ausubel pada tahun 1992 (Basleman, 2011). (Cahyani, 2010) menyatakan model pembelajaran advance organizer adalah suatu model pembelajaran bermakna, dari Ausubel "Penerapan Model Pembelajaran advane organizer untuk Meningkatkan Aktivitas Belajar dan Hasil Belajar Siswa pada Mata Pelajaran IPS Siswa Kelas VII di Mts. Al- Khairiyah Tegallinggah Tahun Pelajaran 2017/2018".

\section{METODE}

Penelitian ini merupakan penelitian terapan kelas (Classsrom Applied Research) yang bertujuan untuk meningkatkan aktivitas dan hasil belajar siswa kelas VII MTs Al-Khairiyah di Tegallinggah Kabupaten Buleleng tahun pelajaran 2018/2019 melalui penerapan model pembelajaran advance organizer. Penelitian ini diawali dengan refleksi hasil pengamatan dan wawancara peneliti dengan guru mata pelajaran IPS kelas VII MTs Al-Khairiyah Tegallinggah Kabupaten Buleleng tahun pelajaran 2018/2019, untuk dapat mengamati lebih jelas masalah yang terjadi dalam proses pembelajaran di kelas. Penelitian ini bersifat kolaboratif karena tidak hanya upaya peneliti dan siswa saja, tetapi peneliti juga bekerja sama dengan guru pengajar mata pelajaran IPS kelas VII MTs Al-Khairiyah di Tegallinggah Kabupaten Buleleng.

Penelitian ini dilakukan di kelas VII di MTs Al-Khairiyah Jl. Angling Darma Desa Tegallinggah Kecamatan Sukasada Singaraja, Buleleng. Subjek dalam penelitian ini adalah siswa-siswi kelas VII MTs Al-Khairiyah Tegallinggah yang berjumlah 23 orang pada tahun 2018/2019. Dari jumlah tersebut terdapat 13 siswa laki-laki dan 10 siswa perempuan. Adapun yang menjadi objek dalam penelitian ini adalah hasil belajar IPS siswa-siswi kelas VII MTs Al-Khairiyah Tegallinggah tahun pelajaran 2018/2019 melalui penerapan model pembelajaran advance organizer.

Dengan demikian proses penelitian ini melibatkan guru mata pelajaran IPS bekerjasama untuk memperbaiki kualitas hasil belajar melalui penelitian tindakan. Penelitian tindakan ini menggunakan beberapa siklus, masing-masing siklus terdiri dari 4 (empat) langkah. Sebelum memasuki siklus diadakan refleksi awal untuk memperoleh gambaran serta mengetahui hal-hal apa saja yang harus diperbaiki. Setelah refleksi awal diupayakan alternatif pemecahan masalah yang ditemukan dengan menggunakan 2 ( dua) siklus yang terdiri dari 4 (empat) langkah yaitu, pertama perencanaan, kedua pelaksanaan, ketiga observasi atau evaluasi, keempat refleksi. Melalui langkah-langkah tersebut, hasil refleksi siklus I akan diambil tindakan pada siklus berikutnya dengan melanjutkan materi pelajaran yang sebelumnya.

Untuk penjabaran dari rancangan penelitian tersebut secara rinci dapat dilihat pada prosedur tindakan sebagai berikut.

\section{Refleksi Awal}

Sebelum melalukan penelitian, peneliti mengadakan refleksi awal meliputi penelitian awal dan wawancara yang dilakukan dengan guru mata pelajaran IPS kelas VII Mts Al-Khairiyah Tegallinggah. Refleksi awal dilaksanakan untuk memperoleh gambaran yang lebih jelas mengenai masalah yang dihadapi guru dalam melaksanakan kegiatan pembelajaran di sekolah bersangkutan yang terkait dengan pembelajaran IPS.

Berdasarkan hasil penelitian awal yang dilakukan melalui wawancara dengan Marazainal Adipta, M.Pd sebagai guru mata pelajaran IPS kelas VII MTs AlKhairiyah Tegallinggah, terungkap beberapa permasalahan sebagai berikut. Pertama,Siswa kurang aktif bertanya pada saat guru menjelaskan materi dan siswa hanya menjawab saat guru memberikan pertanyaan. Kedua, siswa kurang terbiasa belajar mandiri. Ketiga, dalam kegiatan diskusi siswa cenderung pasif. Keempat, media pembelajaran yang digunakan guru dalam mengajar hanya menggunakan buku paket dengan jumlah yang terbatas sehingga proses pembelajaran kurang 
efektif. Berdasarkan permasalahan yang dapat diidentifikasi, maka salah satu alternatif yang dapat digunakan untuk mengatasi masalah tersebut adalah dengan menggunakan model pembelajaran advance organizer.

Melalui penerapan model pembelajaran advane organizer ini diharapkan dapat membantu menyelesaikan permasalahan yang terjadi, baik itu permasalahan yang dialami siswa maupun guru, sehingga dapat menumbuh kembangkan hasil belajar siswa. Untuk mengatasi permasalahan tersebut akan dilaksanakan tindakan yang terbagi menjadi beberapa siklus. Adapun tindakan yang dilaksanakan pada tiap siklus.

\section{Siklus I}

Siklus I dilaksanakan dalam 3 kali pertemuan yaitu 2 kali pertemuan untuk pelaksanaan pembelajaran dan 1 kali pertemuan untuk pelaksanaan tes. Materi pokok yang dibahas dalam siklus ini adalah "Mendeskripsikan hubungan antara kelangkaan sumber daya dengan kebutuhan manusia yang tidak terbatas". Pada siklus I akan dikembangkan menjadi empat tahap yaitu sebagai berikut.

\section{Tahap Perencanaan Siklus I}

Kegiatan yang dilakukan pada tahap perencanaan meliputi pertama, mensosialisasikan kepada guru mata pelajaran IPS kelas VII Mts Al-Khairiyah Tegallinggah dengan model advance organizer, kedua menyepakati jadwal pelaksanaan penelitian, ketiga penentuan materi pembelajaran oleh peneliti bersama guru serta merumuskan indikator pembelajaran untuk masing-masing pertemuan berdasarkan kompetensi dasar, keempat menyusun Rencana Pelaksanaan Pembelajaran (RPP) sebagai pedoman untuk melaksanakan proses pembelajaran sesuai dengan langkah-langkah model pembelajaran advance organizer, kelima peneliti bersama guru mempersiapkan berbagai instrumen pengumpulan data yang meliputi: tes dengan soal objektif dan tugas-tugas beserta format penelitian untuk mengetahui hasil belajar siswa dan pedoman observasi untuk mengetahui aktivitas siswa, keenam menyiapkan media pembelajaran yang akan digunakan dalam kegiatan pembelajaran.

\section{Pelaksanaan Tindakan Siklus I}

Pada tahap pelaksanaan tindakan ini, guru melaksanakan pembelajaran berdasarkan rencana pembelajaran yang telah disusun pada tahap perencanaan yaitu pembelajaran yang mengacu pada penerapan model advance organizer.

Adapun langkah-langkah dalam pelaksanaan siklus I yaitu: guru menyampaikan kompetensi yang akan dicapai, guru menyajikan atau mendemonstrasikan materi sesuai topik dengan tanya jawab, siswa membentuk kelompok terdiri dari 4-5 orang, guru membagikan benda-benda kecil seperti kartu warna-warni, kancing, potongan sedotan, kelereng kecil, dan sebagainya yang befungsi sebagai tanda untuk anggota kelompok yang akan mengemukakan pendapat. Satu benda memiliki satu pendapat atau sanggahan tentang permasalahan materi pembelajaran, Siswa mendapatkan Lembar Diskusi Siswa (LDS) untuk dikerjakan bersama kelompoknya, pada saat diskusi setiap kali siswa mengeluarkan pendapat dalam kelompoknya, siswa harus menyerahkan salah satu benda dengan diletakkan ditengah-tengah kelompok. Apabila benda seorang siswa telah habis, maka dia tidak bisa mengemukakan pendapat lagi sampai semua temannya dalam kelompok tersebut menghabiskan benda yang dipegang mereka, jika semua benda sudah habis sedangkan tugas belum selesai, maka kelompok lain bisa mengambil kesepakatan untuk membagi kembali benda tersebut dan mengulangi prosedurnya kembali tanpa mengabaikan waktu pengajaran, guru pada proses ini berperan sebagai fasilitator dan motivator, pertama guru memberikan kesempatan kepada salah satu kelompok siswa untuk mempresentasikan hasil diskusinya di depan kelas, kedua guru melakukan evaluasi kepada setiap siswa dan kelompok, dari kegiatan evaluasi ini didapat nilai individu dan nilai kelompok, dan guru memberikan reward pada siswa yang memperoleh nilai individu atau kelompok yang mendapat nilai yang tinggi dan penutup, siklus I diakhiri dengan pemberian hasil tes belajar. 


\section{Observasi dan Evaluasi Siklus I}

Semua kegiatan dalam penelitian yang penelitian lakukan akan dilaksanakan bersama guru IPS kelas VII MTs AlKhairiyah Tegallinggah. Selama proses pembelajaran berlangsung dilakukan pengamatan terhadap aktivitas belajar siswa. Observasi yang dilakukan dengan menggunakan lembar observasi. Observasi yang dilakukan meliputi observasi aktivitas siswa serta observasi terhadap pelaksanaan tindakan yaitu mencatat kejadian yang berkaitan dengan proses pembelajaran, mencatat kekurangan dan kendala yang dialami selama proses pembelajaran. Peneliti dan guru akan membagi tugas sebagai pelaksana tindakan dan sebagai pemantau pelaksanaan tindakan.

Pada setiap akhir siklus diadakan evaluasi, dalam hal ini yang dievaluasi adalah hasil belajar siswa dengan memberikan tes objektif serta mengevaluasi kendala-kendala dan kesulitan yang ditemukan selama pelaksanaan tindakan.

\section{Refleksi}

Kegiatan pada tahap ini yaitu merefleksi tindakan yang telah dilakukan selama siklus I, sebagai dasar refleksi adalah hasil tes evaluasi dan hasil observasi sikap siswa selama proses pembelajaran. Refleksi dilakukan dengan tujuan untuk melihat kelemahan dan kendala-kendala yang dihadapi dalam proses pembelajaran pada siklus I, kemudian didiskusikan dengan guru mata pelajaran IPS dan dicari alternatif penyelesaiannya. Hasil dari refleksi ini digunakan sebagai acuan untuk pelaksanaan tindakan pada siklus II. Refleksi mengenai keberhasilan yang telah dicapai akan tetap dipertahankan pada siklus selanjutnya.

Jenis data yang digunakan dalam

penelitian ini adalah data kuantitatif. Data kuantitatif yang digunakan berupa data hasil belajar siswa yang telah dikuantitatifkan dalam penelitian. Menurut, sumber data yang digunakan dalam penelitian ini adalah data primer. Data hal ini berupa data hasil belajar siswa terhadap penerapan model pembelajaran advance organizer.

Metode pengumpulan data pada penelitian ini menggunakan beberapa metode, diantaranya: metode tes, observasi, dan metode dokumentasi.

Tes merupakan metode pengumpulan data yang sifatnya mengevaluasi hasil proses (pre-test dan post-test). Instrumennya dapat berupa soal-soal ujian atau soal-soal tes (Daryanto, 2012). Dalam penelitian ini, metode tes digunakan untuk mengumpulkan data hasil belajar siswa dan tes yang digunakan untuk mengumpulkan data adalah tes akhir (post-test). Observasi ialah metode pengumpulan data secara sistematis melalui pengamatan dan pencatatan terhadap fenomena yang diteliti (Daryanto, 2012). Metode ini digunakan untuk mengumpulkan data aktivitas belajar siswa dalam proses pembelajaran dengan model pembelajaran advance organizer. Alat pengumpulan datanya berupa lembar observasi. Metode dokumentasi dilakukan untuk mengumpulkan data yang bersumber dari arsip atau dokumen yang berada di sekolah. Metode dokumentasi dipergunakan untuk memperoleh data tentang hasil belajar siswa, foto atau rekaman proses belajar mengajar di kelas. Instrumen Pengumpulan Data Hasil Belajar instrumen yang digunakan dalam menentukan hasil belajar siswa dalam penelitian ini adalah tes akhir (post-test). Bentuk tes yang digunakan adalah tes objektif. Untuk mengetahui adanya peningkatan hasil belajar siswa pada siklus I, II dan seterusnya digunakan rumus sebagai berikut.

Pertama rumus untuk mengetahui daya serap kompetensi pemahaman konsep siswa (DDS) menggunakan rumus:

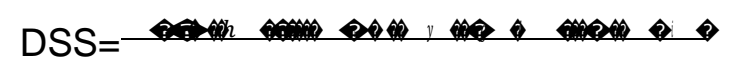

(1)

primer adalah data yang langsung didapatkan dari subjek penelitian, dalam 
Kedua rumus untuk mengetahui persentase ketuntasan belajar siswa secara klasikal akan dihitung dengan rumus sebagai berikut (Candiasa, 2010). 


$$
K B=\frac{S}{N} \times 100 \%
$$

Keterangan :

$\mathrm{KB}=$ Ketuntasan Belajar

$\mathrm{S}=$ Jumlah siswa yang mencapai ketuntasan
$\mathrm{N} \quad=$ Jumlah siswa

Dengan ketentuan berikut, data rata-rata hasil belajar siswa kemudian dikonversi untuk mengetahui kategori nilai siswa seperti tabel berikut.

Tabel 1 pedoman Konversi Skor Hasil Belajar Siswa

\begin{tabular}{cc}
\hline SK & Kategori \\
\hline $85-100$ & Amat baik \\
$75-84$ & Baik \\
$65-74$ & Cukup \\
$41-64$ & Kurang \\
$0-40$ & Sangat kurang \\
\hline
\end{tabular}

Jumlah soal yang digunakan dalam tes hasil belajar siswa adalah 20 butir soal. Setiap butir soal memiliki skor 10 sehingga total skor maksimal adalah 200 . Selanjutnya skor mentah tersebut di konversi menjadi nilai hasil belajar dengan membagi 2 skor mentah tersebut, sehingga skor maksimum yang diperoleh kemudian dikualifikasikan berdasarkan kriteria ketuntasan minimal (KKM) yang telah di terapkan oleh sekolah yaitu 70 untuk mata pelajaran IPS. Untuk skor hasil belajar siswa yang dianalisis dengan teknik kuantitatif akan dikonversi seperti di tabel:

Tabel 2 kriteria Ketuntasan Hasil Belajar Siswa

\begin{tabular}{cc}
\hline Hasil belajar siswa & Kualifikasi \\
\hline $70-100$ & Tuntas \\
$0-69$ & Belum Tuntas \\
\hline
\end{tabular}

Berdasarkan kualifikasi di atas, seorang siswa dinyatakan berhasil (tuntas) jika telah memperoleh nilai minimal 70 , sedangkan siswa yang memperoleh nilai kurang dari 70 dianggap belum berhasil (belum tuntas).

\section{HASIL DAN PEMBAHASAN Hasil Penelitian}

Pada hasil penelitian ini, akan dijelaskan secara rinci mengenai pelaksanaan kegiatan penelitian yang direncanakan dengan tindakan sebanyak II siklus. Setiap siklus akan diawali dengan beberapa tahapan yang harus dilakukan. Tahapan tersebut meliputi beberapa hal yaitu perencanaan sebelum tindakan, pelaksanaan tindakan atau action, dilanjutkan melakukan observasi meliputi pemberian tes hasil belajar siswa, serta langkah yang terakhir adalah refleksi. Secara detail akan dibahas di bawah ini.

\section{Pelaksanaan Tindakan Model Pembelajaran advance organizer pada Siklus I}

Pada siklus I, ada empat tahapan yang harus dilalui. Adapun tahapan tersebut adalah perencanaan, pelaksanaan tindakan, pengamatan, dan refleksi.

\section{Perencanaan}

Pada tahap awal perencanaan, guru dan penulis terlebih dahulu menentukan pokok bahasan yang mengacu pada proses pembelajaran yang sedang berlangsung. Kemudian, penulis menyusun RPP yang di dalamnya terdapat langkah-langkah pembelajaran Advance Organizer, yang diharapkan dapat meningkatkan hasil belajar siswa. Setelah menyusun RPP, penulis dibantu oleh guru membuat Lembar Kerja Siswa (LKS) untuk memfasilitasi siswa dalam kegiatan pembelajaran yang akan 
berlangsung. Pada penelitian ini, penulis juga membuat instrumen tes yang digunakan untuk mengukur hasil belajar siswa, yang mengacu pada pokok bahasan pada setiap pertemuan. Selain itu, penulis juga mempersiapkan materi yang nantinya akan digunakan untuk mendukung penerapan model pembelajaran advance organizer.

\section{Tindakan}

Proses pelaksanaan tindakan siklus I terbagi menjadi dua kali pertemuan, yang mana pada masingmasing pertemuan berlangsung selama 3 x 45 menit. Secara rinci pelaksanaan tindakan pada setiap pertemuan adalah sebagai berikut:

\section{Pertemuan pertama 3x 45 menit}

Proses tindakan yang dilakukan pada pertemuan I yaitu melaksanakan Penelitian Tindakan Kelas (PTK) siklus I. Pada penelitian ini, penulis bertindak sebagai guru dan guru mata pelajaran bertindak sebagai pengamat aktif. Mulamula guru membuka pelajaran dengan salam, yang dilanjutkan dengan presensi dan menanyakan keadaan kelas untuk mengetahui peserta didik yang tidak masuk sekolah dan apa alasannya. Selanjutnya guru menjelaskan tujuan pembelajaran yang akan dicapai pada pertemuan pertama ini, antara lain menyebutkan pengertian permintaan dan penawaran, menyebutkan hukum permintaan dan penawaran, dan menyebutkan fakor yang mempengaruhi permintaan dan penawaran, menyebutkan harga keeimbangan dan grafis harga keseimbangan. yang diharapkan setelah pembelajaran ini, siswa dapat mencapai tujuan pembelajaran yang diharapkan. Tindakan selanjutnya adalah, peserta didik dimotivasi dengan cara menjelaskan ruang lingkup materi permintaan dan penawaran pada siswa. Lalu, siswa diberikan beberapa pertanyaan yang berkaitan dengan permintaan dan penawaran, seperti seperti bunyi hukum permintaan dan penawaran. Kemudian, guru menunjuk salah satu siswa untuk menjawabnya, dan jika siswa tersebut menjawab dengan benar, guru memberikan pernyataan penghargaan secara verbal seperti "bagus sekali". pernyataan penghargaan secara verbal merupakan cara paling mudah dan efektif untuk meningkatkan semangat belajar siswa agar berdampak terhadap hasil belajar yang baik, apalagi kalau penghargaan verbal itu diberikan di depan orang banyak. Kemudian, guru memandu siswa untuk menerapkan model pembelajaran advance organizer. Pada tahap pelaksanaan tindakan ini, guru melaksanakan pembelajaran berdasarkan rencana pembelajaran yang telah disusun pada tahap perencanaan yaitu pembelajaran yang mengacu pada penerapan model advance organizer.

Adapun langkah-langkah dalam pelaksanaan sebagai berikut.

Pertama guru menjelaskan tujuan satuan pelajaran.

Kedua guru menyajikan organizer materi permintaan dan penawaran sesuai topik dengan tanya jawab yang mencangkup materi permintaan dan penawaran, dan memberkan contoh permintaan dan penawaran.

Ketiga guru membentuk kelompok terdiri dari 4-5 orang agar memudahkan penyamaian materi untuk mendorong timbulnya kesadan siswa akan pengetahuan dan pengalaman yang relevan dengan sesama peserta belajar .

Keempat guru membagikan benda-benda kecil seperti kartu warna-warni, kancing, potongan sedotan, kelereng kecil, dan sebagainya yang befungsi sebagai tanda untuk anggota kelompok yang akan mengemukakan pendapat. Satu benda memiliki satu pendapat atau sanggahan tentang permasalahan materi pembelajaran.

Kelima siswa mendapatkan Lembar Diskusi Siswa (LDS) untuk dikerjakan bersama kelompoknya.

Keenam pada saat diskusi, setiap kali siswa mengeluarkan pendapat dalam kelompoknya, siswa harus menyerahkan salah satu benda dengan diletakkan ditengah-tengah kelompok. Apabila benda seorang siswa telah habis, maka dia tidak bisa mengemukakan pendapat lagi sampai semua temannya dalam kelompok tersebut menghabiskan benda yang dipegang mereka. Jika semua benda 
sudah habis sedangkan tugas belum selesai, maka kelompok bisa bisa mengambil kesepakatan untuk membagi kembali benda tersebut dan mengulangi prosedurnya kembali tanpa mengabaikan waktu pengajaran. Guru pada proses ini berperan sebagai fasilitator dan motivator. Ketujuh guru memberikan kesempatan kepada salah satu kelompok siswa untuk mempresentasikan hasil diskusinya di depan kelas.

Kedelapan guru melakukan evaluasi kepada setiap siswa dan kelompok yang belum mengerti, Kemudian guru memberikan soal tes kepada siswa untuk mengetahui daya serap siswa terhadap materi yang telah diajarkan.

Kesembilan guru memberikan reward pada siswa yang memperoleh nilai individu atau kelompok yang mendapat nilai yang tinggi. Kesepuluh kegiatan terakhir dalam pembelajaran siklus I pertemuan pertama diakhiri dengan pemberian tugas kepada siswa.

\section{Pertemuan kedua $3 \times 45$}

Pada proses tindakan pada pertemuan kedua, penulis masih bertindak sebagai guru. Seperti halnya siklus I, mula-mula guru membuka pelajaran dengan salam. Kemudian guru mengabsen kehadiran siswa, dan menyiapkan kondisi kelas untuk proses pembelajaran. Selanjutnya, guru menyampaikan tujuan pembelajaran yang akan dicapai pada pertemuan yang kedua, antara lain tentang pasar, fungsi pasar. Kemudian guru memotivasi siswa dengan cara memberikan pertanyaan kepada siswa seputar pasar, dan menunjuk salah satu murid untuk menjawab pertanyaan yang diberikan. Untuk menambah motivasi, guru memberikan penghargaan verbal apabila siswa benar dalam menjawab pertanyaan yang diajukan. Untuk kegiatan inti pada pertemuan kedua sama dengan kegiatan inti pada pertemuan pertama.

\section{Pengamatan Data Hasil Belajar Siswa Siklus I}

Prestasi belajar siswa pada siklus pertama diukur dengan memberikan tes pada peserta didik setelah dilakukan tindakan. Tujuan dari pemberian tes ini dimaksudkan untuk mengetahui sejauh mana prestasi siswa setelah dilakukan tindakan. Berdasarkan hasil analisis data pada siklus I dalam dua kali pertemuan, dengan pokok bahasan pada pertemuan pertama "pengertian permintaan dan penawaran, faktor-faktor yang mempengaruhi permintaan dan penawaran, fungsi permintaan dan penawaran, hukum permintaan dan penawaran serta asumsi-asumsinya, kurva permintaan dan penawaran, proses terbentuknya keseimbangan pasar, dan elastisitas permintaan dan penawaran" dan pada pertemuan kedua "pengertian pasar, peran pasar dalam perekonomian, macam-macam pasar, struktur pasar atau bentuk pasar, dan peran Iptek terhadap perubahan jenis dan struktur pasar".

Perolehan data hasil belajar siswa pada siklus I menunjukkan bahwa nilai tertinggi yang mampu dicapai oleh siswa adalah 85 , sementara nilai terendah yang di peroleh siswa adalah 55. Siswa yang memperoleh nilai pada rentangan 85-100 sebanyak 4 orang $(17,39 \%)$, siswa yang memperoleh nilai pada rentangan 75-84 sebanyak 7 orang $(30,43 \%)$, siswa yang memperoleh nilai pada rentangan 65-74 sebanyak 5 orang $(21,74 \%)$, siswa yang memperoleh nilai pada rentangan 41-64 sebanyak 7 orang $(30,43 \%)$, dan tidak ada siswa yang memperoleh nilai pada rentangan 0-40. Rata-rata hasil belajar siswa pada siklus I adalah 70,65 dengan kategori hasil belajar adalah cukup. Perolehan hasil belajar siswa pada siklus I tersebut dapat dilihat pada gambar 1 diagram berikut.

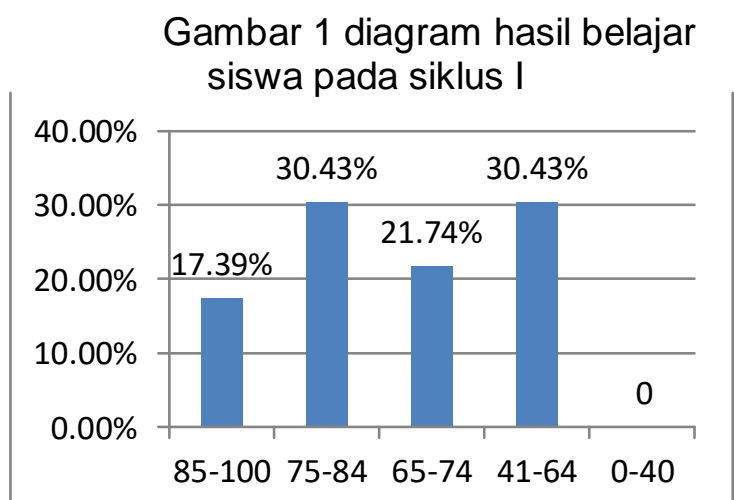

Berdasarkan hasil belajar siswa pada siklus I dapat diketahui jumlah siswa yang sudah tuntas dalam pembelajaran IPS 
sebanyak 14 orang $(60,87 \%)$ dan siswa yang belum tuntas dalam pembelajaran IPS sebanyak 9 orang (39,13\%) dengan Kriteria Ketuntasan Minimal (KKM) yang ditetapkan untuk mata pelajaran IPS di
MTs Al-Khairiyah Tegalinggah yaitu 70 . Data ketuntasan belajar siswa pada mata pelajaran IPS pada akhir siklus I dapat dilihat pada tabel berikut.

Tabel 3 Sebaran Frekuensi Ketuntasan Belajar Siswa Siklus I

\begin{tabular}{ccc}
\hline Keterangan & Jumlah Siswa & Presentase \\
\hline Tuntas & 14 orang & $60,87 \%$ \\
Tidak Tuntas & 9 orang & $39,13 \%$ \\
Jumlah & 23 orang & $100,00 \%$ \\
\hline
\end{tabular}

Sebaran ketuntasan belajar siswa pada siklus I dapat dilihat pada gambar diagram berikut.

Gambar 2 Diagram Persentase Sebaran Ketuntasan Belajar Siswa Siklus I

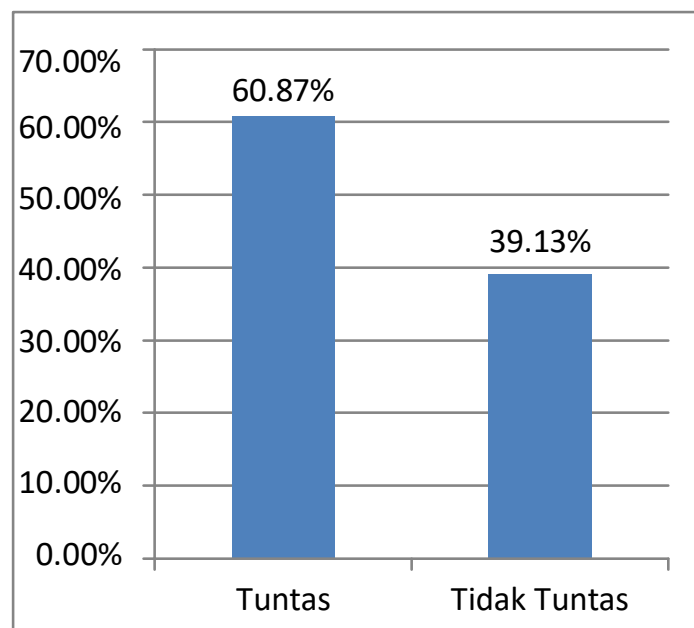

\section{Refleksi Dan Rencana Perbaikan}

Setelah selesai melaksanakan penelitian tindakan pada siklus I, guru bersama dengan penulis melakukan refleksi berdasarkan permasalahanpermasalahan yang ditemukan pada siklus I, antara lain:

Pertama siswa yang ditunjuk untuk mempresentasikan jawabannya di depan kelas masih membawa dan membaca teks jawaban hasil diskusi kelompok. Hal ini menunjukkan kurangnya kepercayaan diri dan pemahaman siswa dalam menyampaikan jawabannya. Kedua prestasi hasil belajar siswa masih rendah. Hal ini ditunjukkan dengan hanya ada 14 siswa yang yang tuntas dan siswa yang belum tuntas sebanyak 9 orang dengan kriteria ketuntasan minaimal (KKM) ang telah ditetapkan sekolah MTs Al-Khairiyah Tegallinggah yaitu sebesar 70 . Ketiga motivasi siswa terhadap pembelajaran masih belum sesuai yang diharapkan penulis.

Adapun rencana perbaikan yang akan dilakukan untuk perbaikan siklus II antara lain: pertama pada saat akan presentasi, guru meminta kepada siswa menjawab tanpa membawa dan membaca jawaban hasil diskusi ke depan kelas. Kedua untuk meningkatkan dalam hal prestasi dan hasil belajar siswa, guru mengingatkan kepada peserta didik untuk selalu belajar di rumah, dan juga untuk selalu serius dalam mengikuti setiap proses pembelajaran yang dilaksanakan.

Berdasarkan refleksi siklus I dapat diperoleh kesimpulan bahwa hasil analisis hasil belajar siswa, masih dikatakan rendah karena hanya 12 siswa yang mendapat nilai 7,00. Dari keseluruhan pengamatan yang dilakukan, maka guru dan penulis sepakat penelitian ini berlanjut ke siklus II.

\section{Pelaksanaan Tindakan Model Pembelajaran advance organizer pada Siklus II}

Seperti halnya siklus I, pada siklus II ada beberapa tahapan yang harus ditempuh. Implementasi dari tahapan tersebut yaitu perencanaan, pelaksanaan tindakan, pengamatan, dan refleksi.

\section{Perencanaan}

Berangkat dari kekurangan yang ada pada siklus I dan merujuk pada refleksi dan rencana perbaikan yang akan dilakukan, maka rencana pelaksanaan pembelajaran pada siklus II adalah mempersiapkan RPP yang akan 
digunakan. Penulis dibantu dengan guru membuat RPP yang akan digunakan sebagai panduan agar pembelajaran yang dilakukan sesuai dengan tujuan yang diinginkan. Seperti halnya siklus I, pada RPP siklus II juga masih terdapat langkah-langkah dalam pembelajaran advance organizer. Penulis juga membuat Lembar Kerja Siswa (LKS) sebagai penunjang dalam proses pembelajaran. Dan tak lupa, penulis juga membuat soal untuk mengevaluasi pemahaman siswa terhadap materi pembelajaran yang diberikan setelah proses belajar mengajar berlangsung.

\section{Pelaksanaan}

Seperti halnya siklus I, proses pelaksanaan tindakan siklus II terbagi menjadi dua kali pertemuan yaitu:

\section{Pertemuan pertama $3 \times 45$ menit}

Pelaksanaan tindakan pada siklus II pertemuan pertama ini penulis masih bertindak sebagai guru, dan guru mata pelajaran sebagai pengamat aktif. Pada awal pertemuan, guru mula-mula membuka pelajaran dengan salam. Tidak lupa, guru menanyakan keadaan kelas dan presensi untuk mengetahui peserta didik yang tidak hadir. Langkah selanjutnya, guru menyampaikan tujuan pembelajaran pada tindakan siklus kedua pertemuan pertama ini yang meliputi menjelaskan pengertian bank sentral, menyebutkan wewenang dan tujuan bank sentral, dan menjelaskan fungsi bank sentral (Bank Indonesia). Kemudian, guru memandu siswa untuk melaksanakan model pembelajaran advance organizer yang meliputi: Pertama guru menjelaskan tujuan satuan pelajaran. Kedua guru menyajikan organizer materi permintaan dan penawaran sesuai topik dengan tanya jawab yang mencangkup materi permintaan dan penawaran, dan memberkan contoh permintaan dan penawaran. Ketiga guru membentuk kelompok terdiri dari 4-5 orang agar memudahkan penyamaian materi untuk mendorong timbulnya kesadan siswa akan pengetahuan dan pengalaman yang relevan dengan sesama peserta belajar. Keempat guru membagikan benda-benda kecil seperti kartu warnawarni, kancing, potongan sedotan, kelereng kecil, dan sebagainya yang befungsi sebagai tanda untuk anggota kelompok yang akan mengemukakan pendapat. Satu benda memiliki satu pendapat atau sanggahan tentang permasalahan materi pembelajaran. Kelima siswa mendapatkan Lembar Diskusi Siswa (LDS) untuk dikerjakan bersama kelompoknya. Keenam pada saat diskusi, setiap kali siswa mengeluarkan pendapat dalam kelompoknya, siswa harus menyerahkan salah satu benda dengan diletakkan ditengah-tengah kelompok. Apabila benda seorang siswa telah habis, maka dia tidak bisa mengemukakan pendapat lagi sampai semua temannya dalam kelompok tersebut menghabiskan benda yang dipegang mereka. Jika semua benda sudah habis sedangkan tugas belum selesai, maka kelompok bisa bisa mengambil kesepakatan untuk membagi kembali benda tersebut dan mengulangi prosedurnya kembali tanpa mengabaikan waktu pengajaran. Guru pada proses ini berperan sebagai fasilitator dan motivator. Ketujuh guru memberikan kesempatan kepada salah satu kelompok siswa untuk mempresentasikan hasil diskusinya di depan kelas. Kedelapan guru melakukan evaluasi kepada setiap siswa dan kelompok yang belum mengerti, Kemudian guru memberikan soal tes kepada siswa untuk mengetahui daya serap siswa terhadap materi yang telah diajarkan. Kesembilan guru memberikan reward pada siswa yang memperoleh nilai individu atau kelompok yang mendapat nilai yang tinggi.

$$
\text { Kegiatan terakhir dalam }
$$

pembelajaran siklus II pertemuan pertama diakhiri dengan pemberian tugas kepada siswa.

\section{Pertemuan kedua $3 \times 45$ menit}

Pertemuan kedua ini merupakan lanjutan dari pertemuan pertama. Guru mengawali tindakan pada pertemuan ini dengan salam, yang dilanjutkan dengan berdoa, kemudian melakukan presensi terhadap siswa. Tidak lupa, guru dibantu siswa mengkondisikan tempat duduk 
seperti halnya pada pertemuan pertama. Selanjutnya, guru menyampaikan tujuan pembelajaran yang akan dilalui. Dan tidak lupa pula guru memotivasi siswa agar lebih semangat dalam mengikuti pembelajaran. Selanjutnya guru melakukan apersepsi materi pembelajaran yang akan dilalui. Seperti halnya pertemuan pertama, guru melanjutkannya dengan memandu siswa melakukan langkah-langkah pembelajaran advance organizer.

\section{Pengamaan data hasil belajar siswa siklus II}

Berdasarkan analisis data hasil belajar pada siklus II menunjukkan bahwa nilai tertinggi yang mampu dicapai oleh siswa adalah 90 , sementara nilai terendah yang diperoleh siswa adalah 70. Apabila dibandingkan dengan hasil belajar siklus I, menunjukkan adanya peningkatan terhadap hasil belajar siswa.

Hal ini dapat dilihat dari adanya peningkatan jumlah siswa yang memperoleh nilai pada rentangan 85-100 sebanyak 9 orang $(39,13 \%)$, jumlah siswa yang memperoleh nilai pada rentangan 75-84 sebanyak 12 orang (52,17\%), dan jumlah siswa yang memperoleh nilai pada rentangan 65-74 sebanyak 2 orang $(8,70 \%)$. Tidak ada siswa yang memperoleh nilai pada rentangan $41-46$ $(0,00 \%)$, dan $0-46 \quad(0,00 \%)$. Rata-rata hasil belajar siswa pada siklus II adalah 80,65 dengan kategori hasil belajar adalah baik.

Perolehan hasil belajar siswa pada siklus II tersebut dapat dilihat pada gambar diagram berikut.

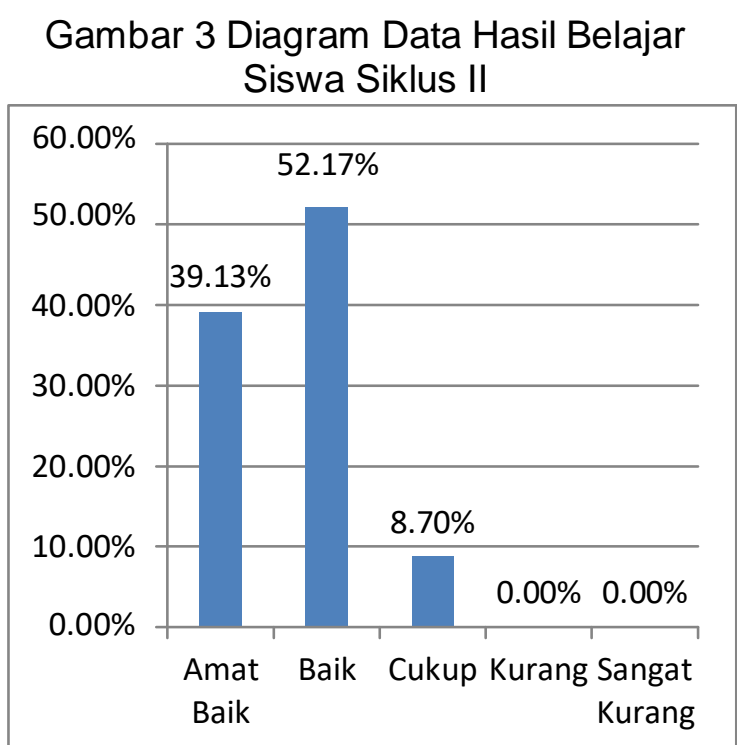

Berdasarkan hasil belajar siswa pada siklus II dapat diketahui seluruh siswa tuntas dalam pembelajaran IPS dengan Kriteria Ketuntasan Minimal (KKM) yang ditetapkan untuk mata pelajaran IPS di MTs Al-Khairiyah Tegallinggah yaitu 70. Data ketuntasan belajar siswa pada mata pelajaran IPS pada akhir siklus II.dapat dilihat pada tabel berikut.

Tabel 4 Sebaran Frekuensi Ketuntasan Belajar Siswa Siklus II

\begin{tabular}{ccc}
\hline Keterangan & Jumlah Siswa & Presentase \\
\hline Tuntas & 22 orang & $95,65 \%$ \\
Tidak Tuntas & 1 orang & $4,3 \%$ \\
Jumlah & 23 orang & $100,00 \%$ \\
\hline
\end{tabular}

\section{Pembahasan}

Berdasarkan hasil penelitian yang telah dilaksanakan dalam dua siklus dengan penerapan model pembelajaran advance organizer, dapat meningkatkan hasil belajar siswa. Dari hasil tindakan, penerapan model pembelajaran advance organizer dikelas VII MTs Al-Khairiyah Tegallinggah dilihat dari kemampuan siswa yang semakin meningkat dalam menjawab tes hasil belajar dari siklus I mengalami peningkatan hasil yang ditunjukkan oleh siswa sesuai dengan data yang dikumpulkan hasil belajar siswa yang dapat dilihat dari adanya kenaikan nilai rata-rata kelas dari 70,65 pada akhir siklus I menjadi 80,65 pada akhir siklus II. Kenaikan hasil belajar ini sesuai dengan penelitian (Amitra, 2010) yang menyatakan bahwa penggunakan model pembelajaran advance organizer memberikan pengaruh yang signifikan terhadap hasil belajar. Berdasarkan 
analisis data hasil belajar siswa yang diperoleh pada siklus I sampai dengan siklus II, maka pelaksanaan tindakan yang dilakukan dapat dikatakan mampu meningkatkan aktivitas dan hasil belajar siswa kelas VII MTs Al-Khairiyah Tegallinggah tahun pelajaran 2018/2019. $\mathrm{Hal}$ ini dapat terjadi karena penerapan model pembelajaran advance organizer dapat membantu siswa secara aktif baik fisik maupun psikologis dalam setiap kegiatan pembelajaran, sehingga mampu untuk meningkatkan hasil belajar IPS siswa.

Sejalan dengan pendapat (Dahar, 2011) advance organizer berguna untuk mengajarkan materi pelajaran yang telah mempunyai struktur teratur, dimana model pembelajaran advance organizer mengarahkan siswa ke materi yang akan mereka pelajari, dan menolong mereka untuk mengingat kembali yang berhubungan serta dapat digunakan dalalm menanamkan pengetahuan baru yang kemudian dikuatkan berdasarkan pendapat (Maryani, 2016) model pembelajaran advance organizer adalah model pembelajaran yang mengaitkan antara pengetahuan baru dengan pengetahuan yang telah ada yang bersumber dari pengalaman siswa sehinggga model pembelajaran ini diharapkan mampu memperkuat struktur kognitif siswa sehingga menambah daya ingat siswa terhadap informasi yang bersifat baru. Sehingga siswa diharapkan dapat mengaitkan informasi yang telah dimiliki dengan materi yang akan diajarkan.

Berdasarkan hasil penelitian yang telah dilaksanakan dalam dua siklus dengan penerapan model pembelajaran advance organizer, dapat meningkatkan hasil belajar siswa. Dari hasil tindakan, penerapan model pembelajaran advance organizer mampu meningkatkan hasil belajar siswa yang dapat dilihat dari adanya kenaikan nilai rata-rata kelas dari 70,65 pada akhir siklus I menjadi 80,65 pada akhir siklus II. Kenaikan hasil belajar ini memberikan dampak bahwa penggunakan model pembelajaran advance organizer memberikan pengaruh yang signifikan terhadap hasil belajar. Berdasarkan analisis data hasil belajar siswa yang diperoleh pada siklus I sampai dengan siklus II, maka pelaksanaan penelitian tindakan yang dilakukan dapat dikatakan mampu meningkatkan hasil belajar siswa kelas VII MTs Al-Khairiyah Tegallinggah tahun pelajaran 2018/2019. Hal ini dapat terjadi karena penerapan model pembelajaran advance organizer di MTs Al-Khiriyah Tegallinggah kelas VII dapat membantu siswa secara aktif baik fisik maupun psikologis dalam setiap kegiatan pembelajaran, sehingga mampu untuk meningkatkan hasil belajar IPS siswa kelas VII di MTs Al-Khiriyah Tegallinggah yang kemudian akan terlihat hasil belajar siswa kelas VII MTs AlKhairiyah dikelas.

Dari paparan di atas, secara umum model pembelajaran advance organizer telah dapat meningkatkan hasil belajar siswa kelas VII MTs Al-Khairiyah Tegallinggah. Dengan kata lain, penelitian ini sudah dapat menjawab pertanyaan dari rumusan masalah sehingga penelitian ini dapat dikatakan berhasil.

\section{SIMPULAN DAN SARAN}

Berdasarkan hasil dan
pembahasan yang telah dilakukan, maka dapat disimpulkan bahwa penerapan model pembelajaran advance organizer dapat meningkatkan hasil belajar siswa pada mata pelajaran IPS siswa kelas VII di MTs Al-Khairiyah Tegallinggah Kabupaten Buleleng. Pada siklus I nilai rata-rata hasil belajar siswa sebesar 70,65 yang berada dalam kategori cukup, jumlah siswa yang sudah tuntas sebanyak 14 orang $(60,87 \%)$ dan jumlah siswa yang belum tuntas sebanyak 9 orang $(39,13 \%)$. Ketuntasan belajar mengalami peningkatan sebesar 13,04\% dari $47,83 \%$ pada observasi awal menjadi $60,87 \%$ pada akhir siklus I, sedangkan pada siklus II nilai rata-rata hasil belajar siswa mengalami peningkatan menjadi 80,65 yang berada pada kategori baik, jumlah siswa yang sudah tuntas sebanyak 22 orang $(95,65 \%)$ dan jumlah siswa yang belum tuntas sebanyak 1 orang $(4,35 \%)$. Ketuntasan belajar juga mengalami peningkatan yang dapat dikatakan sangat tinggi yaitu sebesar $34,78 \%$ dari $60,87 \%$ pada akhir siklus I menjadi 95,65\% pada akhir siklus II. 
Berdasarkan simpulan yang dipaparkan di atas, maka dapat diungkapkan saran terkait dengan hasil penelitian ini adalah sebagai berikut. Pertama disarankan kepada guru MTs AlKhairiyah Tegallinggah Kabupaten Buleleng dapat menerapkan model pembelajaran advance organizer sebagai salah satu model pembelajaran yang dipilih dalam pembelajaran IPS. Karena model pembelajaran advance organizer ini dapat meningkatkan hasil belajar siswa sehingga tujuan pembelajaran yang diharapkan dapat tercapai. Kedua untuk memaksimalkan penerapan model pembelajaran advance organizer perlu adanya reward kepada siswa yang akif di kelas agar siswa lebih semangat, sehingga dapat meningkatkan hasil belajar siswa.

Untuk peneliti selanjutnya hendaknya lebih memperluas lagi penelitian tentang model pembelajaran advance organizer. Dengan menggunakan pokok bahasan yang berbeda untuk mengetahui efektivitas pengimplementasian model pembelajaran advance organizer serta memperhatikan kendala-kendala yang dihadapi peneliti sebagai bahan pertimbangan untuk perbaikan dan penyempurnaan pelaksanaan penelitian berikutnya.

\section{DAFTAR RUJUKAN}

Amitra, A. (2010). Pengaruh Model Pembelajaran Advance Organizer Terhadap Hasil Belajar Kimia Pada Konsep Ikatan Kimia.

Basleman, A. (2011). Teori Belajar Orang Dewasa. Jakarta: PT. Remaja Rosdakarya.

Cahyani, R. (2010). Pembelajaran IPS Kreatif. Jakarta: Balai Pustaka.

Candiasa, I. M. (2010). Pengujian Instrumen Penelitian Disertai Aplikasi Iteman dan Bigsteps. Singaraja: Unit Penerbit Pendidikan Ganesha.

Dahar, A. (2011). Teori Belajar dan Pembelajaran. Jakarta: Erlangga.

Daryanto. (2012). Evaluasi Pendidikan. Jakarta: PT. Rineka ipta.

Depdiknas. (n.d.). Undang-undang RI No.20 tahun 2003.

Maryani, E. (2016). Implementasi Model Pembelajaran Advance
Organzer Menggunakan Animasi

Ditinjau Dari Minat Belajar

Terhadap Hasil Belajar Kognitif

Siswa Kelas VII Pada Pelajaran IPA Di SMPN 1 Batukliang Tahun Ajaran 2014/2015. 2. 